\title{
Comparison of Maximal Aerobic Power between Adolescent Boys and Adolescent Girls of the Northern Central Zone of India
}

\author{
Badshah Ghosh* \\ Department of Physical Education, Panskura Banamali College, Panskura, Purba Medinipur, West Bengal, India \\ *Corresponding author: badshahghosh@yahoo.co.in
}

Received July 18, 2014; Revised July 29, 2014; Accepted August 13, 2014

\begin{abstract}
The present investigation was undertaken by the investigator is an attempt to compare the Maximal Aerobic Power between Adolescent Boys and Adolescent Girls of the northern central zone of India. The subjects for this study were a total of 2010 subjects viz. 1005 boys and 1005 girls. 1005 boys and 1005 girls belonged to three age categories i.e. 12 to below 14 years, 14 to below 16 years and 16 to below 18 years of age. Thus, each age group of boys and girls consisted of 335 subjects. The subjects of the study were selected at random. Only healthy adolescents were selected on the basis of teacher's appraisal. The selected physiological variables was considered important for research because it will provide us a true picture of cardiovascular endurance in general and $\mathrm{VO}_{2}$ max in particular of adolescent boys and girls in north central zone. To compare the Maximal Aerobic Power between Adolescent Boys and Adolescent Girls o north central zone of India, the Descriptive statistics and 't' test was used. Descriptive statistics and 't' test was calculated. The average values of Maximal Aerobic Power of Boys: 12 to below 14 Years $(18.10 \pm 1.79 \mathrm{ml} / \mathrm{kg} / \mathrm{min}), 14$ to below 16 Years $(26.07 \pm 2.80 \mathrm{ml} / \mathrm{kg} / \mathrm{min})$ and 16 to below 18 Years $(37.09 \pm 3.24 \mathrm{ml} / \mathrm{kg} / \mathrm{min})$ respectively. The average values of Maximal Aerobic Power of Girls: 12 to below 14 Years (17.54 $1.98 \mathrm{ml} / \mathrm{kg} / \mathrm{min}), 14$ to below 16 Years $(25.10 \pm 2.84 \mathrm{ml} / \mathrm{kg} / \mathrm{min})$ and 16 to below 18 Years $(35.78 \pm 3.12$ $\mathrm{ml} / \mathrm{kg} / \mathrm{min}$ ) respectively. The present study reveals that significant difference exists between adolescent boys and adolescent girls at different age group (i.e. 12 to below 14 years, 14 to below 16 years and 16 to below 18 years of age) in relation to maximal aerobic power.
\end{abstract}

Keywords: maximal aerobic power, oxygen uptake, adolescent

Cite This Article: Badshah Ghosh, "Comparison of Maximal Aerobic Power between Adolescent Boys and Adolescent Girls of the Northern Central Zone of India." American Journal of Sports Science and Medicine, vol. 2, no. 5A (2014): 10-12. doi: 10.12691/ajssm-2-5A-3.

\section{Introduction}

The modern age is an age of space adventurism and technology. Machines which man built for the purpose of adding comforts to his life, have, now so much pervaded his existence that it is somewhat difficult to do away with the human dependence upon machines, they have became part and parcel of our life and in this process man himself has become an automation. Modern man in comparison to the primitive man is poorer and inferior with regard to physical fitness. Physical fitness is prime necessity to get the outmost out of life and to enable us to live most and serve best. The comment of late J. F. Kennedy, former President of United State of America, emphasized physical fitness as not one of the important keys to a healthy body but as the basis of dynamic and creative intellectual activity. Children are said to be the citizens of tomorrow and builders of the nation. Their smiles inspire the hope and they are the pioneers of a brighter tomorrow. But the state of children in this country is miserably languishing in innocence and silence. The findings of national and international organizations reveal the plight of our children and call for an all out effort to save these withering blossoms from further degeneration and disruption.

Both heredity and environment provide for greater variations in growth. These variations complicate the job of the educator, especially physical educator. An important step in establishing the educational process for children is to understand the nature of the child as revealed by his biological, psychological, emotional and social needs. Teachers, coaches and researchers, who work with children, must understand the needs and characteristics of these children that motivate and structure the behavior of the various age levels (Harold M. Barrow). The physical education teacher must understand the children and their level of physical development and maturity. Several research studies have been undertaken in this field to find out the degree of differences of boys and girls at the same age level in their physical development and maturation. In early childhood, the growth and development of the child goes in a uniform manner. A person with a high $\mathrm{VO}_{2}$ max necessarily has good function 
in each of these determinants. Conversely, a sedentary person has relatively poor function for each determinant, which results in a low $\mathrm{VO}_{2}$ max. The outcome of the study might help physical educators or coaches to evaluate and modify the training programs pertaining to cardiovascular fitness for both boys and girls.

\section{Materials and Methods}

The subjects for this study were a total of 2010 subjects viz. 1005 boys and 1005 girls. 1005 boys and 1005 girls belonged to three age categories i.e. 12 to below 14 years, 14 to below 16 years and 16 to below 18 years of age. Thus, each age group of boys and girls consisted of 335 subjects. The subjects of the study were selected at random. Only healthy adolescents were selected on the basis of teachers of their respective school's appraisal. For the true representation of the subjects the scholar selected them only from the schools of State Government and Private Schools, since students of original natives of that particular area whose parents had been spanning the entire strata in terms of economic consideration belong to those schools. The subjects belonged to different socioeconomic status.

Indirect measurement of maximal aerobic power was applied by using Astrand and Astrand Nomogram. Indirect measurement of maximal aerobic power was conducted because of reliability and administrative feasibility on a large number. To obtain required data for the study a step up test was adopted to assess $\mathrm{VO}_{2}$ max of adolescent boys and girls by Astrand and Astrand Nomogram. For the step up test the subjects were asked to step all the way up on the bench each time with the body erect. The stepping process was performed in four counts as: The stronger foot placed on bench; other foot placed on the bench; stronger foot placed on floor; other foot placed on floor. Soon after the cessation of 5 min. exercise on the bench, heart rate was recorded from 0 to 10 seconds, which was further converted to 60 seconds in terms of number of beats/min. Maximal Aerobic Power $\left(\mathrm{Vo}_{2} \max \right)$ was measured in ml.kg. ${ }^{-1} \cdot \mathrm{min}^{-1}$ using Astrand and Astrand Nomogram.

To characterize soccer players by their selected physiological profile, the descriptive statistics was used.

\section{Results}

The results found after analyzing the data have been presented in the following tables.

Table 1. Mean and Standard Deviation of Different age group Adolescent Boys and Girls in Relation to Maximal Aerobic Power

\begin{tabular}{|l|l|l|l|}
\hline Age category & GENDER & Mean $(\mathrm{ml} / \mathrm{kg} / \mathrm{min})$ & S.D. \\
\hline \multirow{2}{*}{12 to below 14 Years } & Boys & 18.10 & 1.79 \\
\cline { 2 - 4 } & Girls & 17.54 & 1.98 \\
\hline \multirow{2}{*}{14 to below 16 Years } & Boys & 26.07 & 2.80 \\
\cline { 2 - 4 } & Girls & 25.10 & 2.84 \\
\hline \multirow{2}{*}{16 to below 18 Years } & Boys & 37.09 & 3.24 \\
\cline { 2 - 4 } & Girls & 35.78 & 3.12 \\
\hline
\end{tabular}

The average values of Maximal aerobic power of Boys: 12 to below 14 Years $(18.10 \pm 1.79 \mathrm{ml} / \mathrm{kg} / \mathrm{min}), 14$ to below 16 Years $(26.07 \pm 2.80 \mathrm{ml} / \mathrm{kg} / \mathrm{min})$ and 16 to below 18 Years $(37.09 \pm 3.24 \mathrm{ml} / \mathrm{kg} / \mathrm{min})$ respectively. The average values of Maximal aerobic power of Girls: 12 to below 14 Years $(17.54 \pm 1.98 \mathrm{ml} / \mathrm{kg} / \mathrm{min}), 14$ to below 16 Years $(25.10 \pm 2.84 \mathrm{ml} / \mathrm{kg} / \mathrm{min})$ and 16 to below18 Years (35.78 $\pm 3.12 \mathrm{ml} / \mathrm{kg} / \mathrm{min})$ respectively.

Table 2. Mean Comparison of Maximal Aerobic Power between Adolescent boys and Adolescent girls (12 to below 14 Years) in Northern Central Zone of India

\begin{tabular}{|c|c|c|c|c|c|}
\hline $\begin{array}{c}\text { Adolescent } \\
\text { Boys }\end{array}$ & $\begin{array}{c}\text { Adolescent } \\
\text { Girls }\end{array}$ & $\begin{array}{c}\text { Mean } \\
\text { Difference }\end{array}$ & $\begin{array}{c}\text { Std. Error } \\
\text { Difference }\end{array}$ & df & $\mathrm{t}$ \\
\hline 18.10 & 17.54 & 0.56 & 0.146 & 668 & $3.838^{*}$ \\
\hline
\end{tabular}

*Significant at 0.05 level of confidence, $\mathrm{t}_{.05}(668)=1.96$

The above table reveals that significant mean differences was found between Adolescent boys and adolescent girls in relation to Maximal aerobic power as the calculated value of ' $\mathrm{t}$ ' $=3.838$ is greater than the tabulated $\mathrm{t}_{.05}(668)=1.96$.

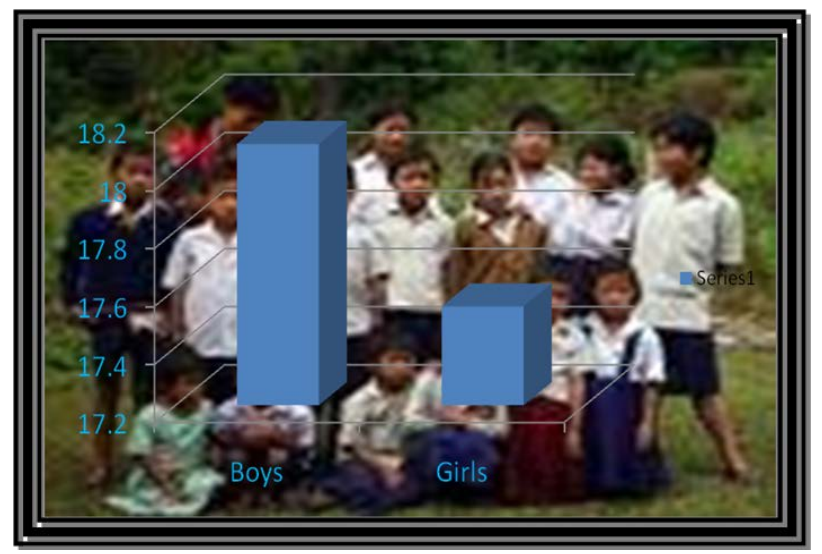

Figure 1. Graphical representation of Maximal Aerobic Power between Adolescent boys and Adolescent girls (12 to below 14 Years) in Northern Central Zone of India

Table 3. Mean Comparison of Maximal Aerobic Power between Adolescent boys and Adolescent girls (14 to below 16 Years) in Northern Central Zone of India

\begin{tabular}{|c|c|c|c|c|c|}
\hline $\begin{array}{c}\text { Adolescent } \\
\text { Boys }\end{array}$ & $\begin{array}{c}\text { Adolescent } \\
\text { Girls }\end{array}$ & $\begin{array}{c}\text { Mean } \\
\text { Difference }\end{array}$ & $\begin{array}{c}\text { Std. Error } \\
\text { Difference }\end{array}$ & df & $\mathrm{t}$ \\
\hline 26.07 & 25.10 & 0.97 & 0.218 & 668 & $4.444^{*}$ \\
\hline
\end{tabular}

*Significant at 0.05 level of confidence; $\mathrm{t}_{.05}(668)=1.96$

The above table reveals that significant mean differences was found between Adolescent boys and adolescent girls in relation to Maximal aerobic power as the calculated value of ' $\mathrm{t}$ ' $=4.444$ is greater than the tabulated $\mathrm{t}_{.05}(668)=1.96$.

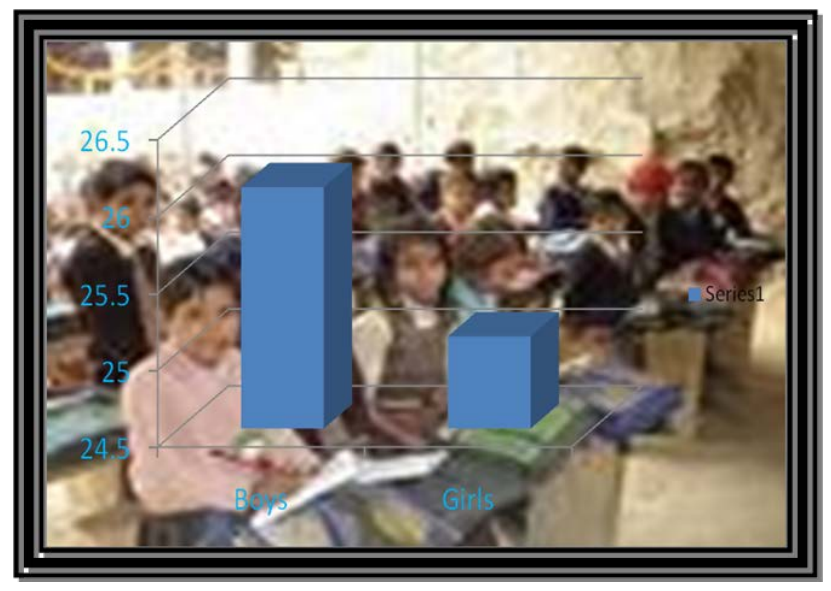

Figure 2. Graphical representation of Maximal Aerobic Power between Adolescent boys and Adolescent girls (14 to below 16 Years) in Northern Central Zone of India 
Table 4. Mean Comparison of Maximal Aerobic Power between Adolescent boys and Adolescent girls (16 to below 18 Years) in Northern Central Zone of India

\begin{tabular}{|c|c|c|c|c|c|}
\hline $\begin{array}{c}\text { Adolescent } \\
\text { Boys }\end{array}$ & $\begin{array}{c}\text { Adolescent } \\
\text { Girls }\end{array}$ & $\begin{array}{c}\text { Mean } \\
\text { Difference }\end{array}$ & $\begin{array}{c}\text { Std. Error } \\
\text { Difference }\end{array}$ & df & $\mathrm{t}$ \\
\hline 37.09 & 35.78 & 1.31 & 0.246 & 668 & $5.30 *$ \\
\hline
\end{tabular}

*Significant at 0.05 level of confidence; $t_{.05}(668)=1.96$.

The above table reveals that significant mean differences was found between Adolescent boys and adolescent girls in relation to Maximal aerobic power as the calculated value of ' $\mathrm{t}$ ' $=5.30$ is greater than the tabulated $\mathrm{t}_{.05}(668)=1.96$.

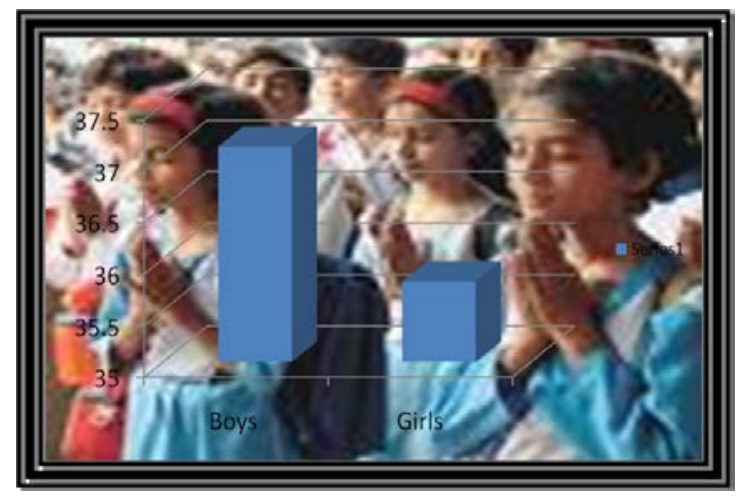

Figure 3. Graphical representation of Maximal Aerobic Power between Adolescent boys and Adolescent girls (16 to below 18 Years) in northern central Zone of India

\section{Discussion and Conclusions}

The present study found that significant difference was found in case of adolescent boys and adolescent girls. The present study can be support by the findings of Andersen LB and et.al in which they have stated that when comparing maximal oxygen uptake per kg lean body mass in the two sexes, the boys had $18.4 \%$ higher values than the girls, indicating that girls of this age have the lower fitness level. Moreover, Eiberg $\mathrm{S}$ and et.al has concluded that $\mathrm{VO}_{2}$ max is higher in boys than girls $(+11 \%)$, even when related to body mass (+8\%) and LBM (+2\%). Most of the difference in $\mathrm{VO}_{2}$ max relative to body mass was explained by the larger percentage body fat in girls. When boys and girls with the same $\mathrm{Vo}_{2}$ max were compared, boys engaged in more minutes of exercise of at least moderate intensity. Thus it is concluded that Adolescent girls possess lesser maximal aerobic power in comparison to adolescent boys.

\section{References}

[1] Harold M. Barrow, Man and Movement: Principles of Physical Education, (Philadelphia: Lea \& Febiger, 1991) p141.

[2] Winefirad Van Hagen, Generic Dexter and Jesse Feiring Williams, Physical Education in the Elementary School (Sueraments: California State Development of Education, 1951), p.3.

[3] Andersen, L.B. et al., "Maximal Oxygen Uptake in Danish Adolescents 16-19 Years of Age”, European Journal of Applied Physiology and Occupational Physiology. 1987;56(1): 74-82.

[4] Eiberg, S. et al. "Maximum Oxygen Uptake and Objectively Measured Physical Activity in Danish Children 6-7 Years of Age: the Copenhagen School Child Intervention Study", British Journal of Sports Medicine. 2005 Oct; 39(10): 725-730.

[5] Astrand, P. and Rhyming, I. "A Nomogram for Calculation of Aerobic Capacity (Physical Fitness) from Pulse during SubMaximal Work.” Journal of Applied Physiology Vol. 7 1954: 218221.

[6] Pivarnik, J.M. et al. "Aerobic Capacity of Black Adolescent Girls" Research Quarterly for Exercise and Sports, 64 (June 1993): 20022007.

[7] Williams, Lois. "Reliability of Predicting Maximal Oxygen Intake Using the Astrand Rhyming Nomogram,” Research Quaterly. 46 (March 1975): 12. 